\title{
The potential of activated carbon derived from bio-char waste of bio-oil pyrolysis as adsorbent
}

\author{
Ariany Zulkania*, Ghina Hanum F., and Amelia Sri Rezki \\ Chemical Engineering Dept., Faculty of Industry Technology, University of Islam Indonesia, Jl. Kaliurang km 14, Yogyakarta, Indonesia
}

\begin{abstract}
Activated carbon from bio-char waste of bio oil pyrolysis of mixed sugarcane bagasse and Rambutan twigs was investigated. Bio-char as by-product of bio-oil pyrolysis has potential to be good adsorbed by activating process. Bio-chars waste was activated in fixed bed reactor inside furnace without presenting oxygen. Gas $\mathrm{N}_{2}$ and $\mathrm{CO}_{2}$ were employed to drive out oxygen from the reactor and as activator, respectively. One of the best activation treatments is achieved by performing activation in different temperature and time to produce standard activated carbon. The experiment was performed at different temperatures and activation time, i.e. 800,850 , and $900^{\circ} \mathrm{C}$ and 80 and 120 minutes, respectively, to determine the optimal operating condition. Activated carbon was characterized by analysis of moisture content, ash content $\mathrm{pH}$, and methylene blue test. The results showed that optimum activation was at $850^{\circ} \mathrm{C}$ and 80 minute, where activated carbon produced indicated the best adsorption capacity. The ash content and $\mathrm{pH}$ had significant role in resulting good activated carbon.
\end{abstract}

\section{Introduction}

Activated carbon are commonly produced from carbonaceous material such as coal, wood, coconut shell, pine nut shell, rice straw, sugarcane bagasse, etc. Sugarcane bagasse is agricultural by-products that is available in large quantities. Based on Ikatan Ahli Gula Indonesia (IKAGI), about 9.64 million tones sugarcane baggase are produced. But only $60 \%$ of sugarcane bagasse is utilized, such as fuel, raw materials for paper, raw materials for brake canvas, mushroom industry, etc. Some studies utilizing sugarcane bagasse to generate activated carbon have been done [1 - 4]. Goncalves et.al. [4] who investigated activated carbon from pyrolysis of sugarcane bagasse and molasses and $\mathrm{CO}^{2}$ activation found that it was possible to obtain activated carbon with surface up to 900 $\mathrm{m} 2 / \mathrm{g}$ over $4.5 \mathrm{~h}$ activation time. Activation of carbon derived from sugarcane bagasse using microwave was explored by Foo et.al. [5]. It was revealed that activated carbon from sugarcane bagasse could be applied as adsorbent for semi-aerobic landfill leachate. Furthermore, the surface area obtain was up to $1620.69 \mathrm{~m} 2 / \mathrm{g}$ and adsorption capacity for ammonical nitrogen and orthophosphate were 138.46 and $12.81 \mathrm{mg} / \mathrm{g}$, respectively.

Wood waste is potential material for producing activated carbon. Most of wood waste especially twig are untapped. A report released by Winda Lismaya in 2014 [6] said that, in Indonesia, logging residues from 15 trees are $141.87 \mathrm{~m}^{3}$ and around $13.8 \%$ of it is twig. Furthermore, both sugarcane bagasse and twig contain lignoselulose (lignin, selulose, and hemiselulose). Most of the agricultural lignocellulosic biomass is comprised of about $10-25 \%$ lignin, $20-30 \%$ hemicellulose, and 40 $50 \%$ cellulose [7]. Therefore, lignoselulose has potential to generate renewable energy and activated carbon. Activated carbon usually produced by thermal or chemical activation. It is an amorphous solid with large surface area with range is given as $400-2000 \mathrm{~m}^{2} / \mathrm{g}$. Raw materials, activated method and processing condition influence characteristics of activated carbon [8 - 10].

Specific surface area (SSA) could be also predicted from Methyl blue test [11, 12]. El-Geundi et.al. [11] determined SSA of some clays and activated carbons using an equation. Then, the results were compared with the SSA using BET-analysis. There were deviations of the comparations depend on the material. However, this approach could be initial determining of specific surface area.

Activated carbon of the mixture of sugarcane bagasse and twigs has not been investigated. This study was focused on producing activated carbon from biochar as waste of bio-oil pyrolysis from sugarcane bagasse/twig of rambutan mixture. Bio-oil pyrolysis process was performed at temperature of $450^{\circ} \mathrm{C}$ and 15 minutes time retention. The effects of activation temperature and time retention on the biochar are investigated. Particularly, adsorption capacity and surface area are the aims of this study.

\section{Material and Method}

\subsection{Material}

*Corresponding author: ariany.zulkania@uii.ac.id 
Biochar waste from bio-oil pyrolysis of sugarcane bagasse/twig of Rambutan mixture was sieved using the $20+30$ Mesh sieve before being activated. Gas $\mathrm{N}_{2}$ dan $\mathrm{CO}_{2}$ are for activation process.

\subsection{Apparatus}

The experiment to produce activated carbon was performed using lab-scale fluidized bed reactor, according to layout shown on Figure 1.

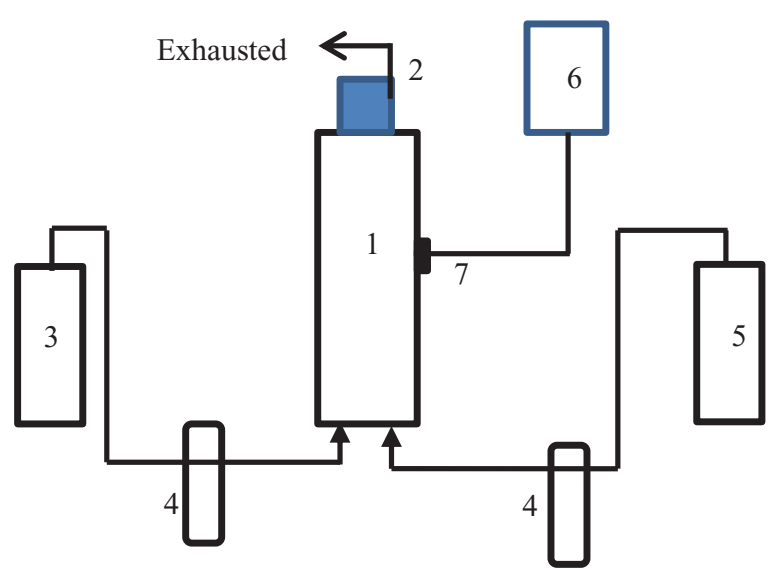
urnance
5. $\mathrm{N}_{2}$ gas tank
2. Fluidized bed reactor
3. $\mathrm{CO}_{2}$ gas tank
4. Flow meter

Fig.1 Apparatus for activating bio-char

The reactor was composed a stainless steel tubular reactor $(7.5 \mathrm{~cm}$ i.d. and $23.5 \mathrm{~cm}$ height $)$ inserted in vertical tubular furnace. The thermocouple probe was inserted to a hole of furnace to measure temperature of the reactor.

\subsection{Experimental Procedure}

Ten grams of biochar poured into a reactor was purged under $\mathrm{N}_{2}$ gas flow $\left(0.5 \mathrm{~cm}^{3} / \mathrm{min}\right)$ until reaching activation temperature. Once reaching the temperature, the flow gas was switched to $\mathrm{CO}_{2}\left(0.5 \mathrm{~cm}^{3} / \mathrm{min}\right)$ and activation was happened over reaction/activating times. After activation, the sample was cooled to room temperature under $\mathrm{N}_{2}$ gas flow. The sample was placed into desiccators for further characterization, except small part for water content analysis was put in a bowl. The following parameters were utilized in this study: activation temperatures of 800 , 850 and $900^{\circ} \mathrm{C}$ and activation times of 80 and $120 \mathrm{~min}$ using heating rate of $10^{\circ} \mathrm{C} / \mathrm{min}$.

\subsection{Activated carbon analysis}

The analysis of activated carbon conducted in this study were water content testing, ash content, $\mathrm{pH}$ testing, and adsorption capacity using methylene blue test. All analysis was carried out in the research laboratories of Chemical Engineering Dept, University of Islamic Indonesia. The results of analysis were then compared to the standard quality of activated carbon properties. According to Indonesian Industrial Standard (SII No. 0258-88), the requirement for the quality of activated carbon is displayed on Table 1.

Table 1. Quality requirement of activated carbon (SII No. 0258 88) [13]

\begin{tabular}{|l|l|}
\hline \multicolumn{1}{|c|}{ Test type } & \multicolumn{1}{c|}{ Requirement (Solid) } \\
\hline Water content & Max. $15 \%$ \\
\hline Ash content & Max. $10 \%$ \\
\hline Fixed karbon (\%) & Min. $65 \%$ \\
\hline $\begin{array}{l}\text { Adsorption capacity of } \\
\text { methylene blue }\end{array}$ & Min. $120 \mathrm{mg} / \mathrm{g}$ \\
\hline
\end{tabular}

\subsubsection{Water content}

Water content was determined to identify hygroscopic property of activated carbon. The calculation of moisture content was based on dry bases. Prior to be dried in oven for one hour at $105^{\circ} \mathrm{C}$, one gram of activated carbon was weighed in a digital-scale. The sample was then, weighed after drying. The water content was calculated using Eq. (1)

$$
\text { Water content }=\frac{a-b}{a} \times 100 \%
$$

Where:

$$
\begin{aligned}
& \mathrm{a}=\text { initial activated carbon weight }(\mathrm{g}) \\
& \mathrm{b}=\text { dried activated carbon weight }(\mathrm{g})
\end{aligned}
$$

\subsubsection{Ash content}

Ash content of activated carbon was determined by heating the sample in the reactor-furnace for two hours at temperature of $800^{\circ} \mathrm{C}$. After heating process, the sample was located in the desiccator for cooling and weighed. The ash content was calculated using Eq.(2)

$$
\text { Ash content }=\frac{\text { ash weight }}{\text { sample weight }} x 100 \%
$$

\subsection{3 $\mathrm{pH}$}

Determination of activated carbon's $\mathrm{pH}$ used Lutron $\mathrm{PH}-$ $201 \mathrm{pHmeter}$. One gram of the sample was poured to water with ratio of 1:9. The mixture was then stirred for 10 minutes to homogenize. The $\mathrm{pH}$ of solution was measured using $\mathrm{pH}$-meter.

\subsubsection{Adsorption capacity of methyl blue}

Adsorption capacity of methylene blue was determined by measuring adsorption isotherm. Here, the adsorption isotherms were determined by the bottle-point method [10], by contacting a constant mass of the adsorbent $(0.1$ g) with $25 \mathrm{~mL}$ of $100 \mathrm{ppm}$ methylene blue solution. The mixture was stirred for 30 minutes to ensure reaching equilibrium. After that, the mixture was filtered to obtain sample solution. Concentration of methylene blue 
solution obtained at the end of all adsorption studies were measured by a UV-vis spectrophotometer with absorbance at 664.00-664.50 nm. Concentration of methylene blue that remained unabsorbed in the solution was determined and percentage of adsorption and amount of methylene blue adsorbed on per gram of activated carbon were calculated by the following Equations [14]

$$
\begin{gathered}
q=\frac{\left(C_{o}-C_{e}\right) \cdot V}{m} \\
\text { Adsorption } \%=\frac{\left(C_{o}-C_{e}\right)}{C_{o}}
\end{gathered}
$$

Where:

$\mathrm{q}=$ amount of methylene blue adsorbed per gram of activated carbon $\left(\mathrm{mg} \cdot \mathrm{g}^{-1}\right)$

Co =initial concentration of methylene blue solution (g.mL $\left.\mathrm{mL}^{-1}\right)$

$\mathrm{Ce}=$ concentration of methylene blue that remained unadsorbed in the solution $\left(\mathrm{g} \cdot \mathrm{mL}^{-1}\right)$

$\mathrm{V}=$ volume of methylene blue solution $(\mathrm{mL})$

$\mathrm{m}=$ mass of activated carbon $(\mathrm{g})$

\subsubsection{Analysis of Surface area}

The concentration of methylene blue remaining on the solution is able to predict surface area of the solid particles $[11,12]$. Surface area of activated carbon was predicted by using following formula

$$
a=\frac{m_{m b}}{319.87 \times m_{s}} A_{v} A_{m b}
$$

Where:

a $=$ specific surface area of activated carbon $\left(\mathrm{m}^{2} \mathrm{~g}^{-1}\right)$

$\mathrm{m}_{\mathrm{mb}}=$ mass of adsorbed methylene blue $(\mathrm{g})$

$\mathrm{m}_{\mathrm{s}}=$ mass of activated carbon $(\mathrm{g})$

$\mathrm{A}_{\mathrm{v}} \quad=$ Avogadro's number $(6.02 * 1023 / \mathrm{mol})$

$\mathrm{A}_{\mathrm{mb}}=$ area covered by one $\mathrm{MB}$ molecule (typically assumed to be $130 \AA^{2}$ )

\section{Result and Discussion}

\subsection{Yield of activated carbon}

Figure 2 shows the yield of activated carbon resulted from varying two variables, those are temperature and activating time. As can be seen, the graphs indicate that increasing of temperature and activating time tend to reduce the yield. This phenomenon was comparable with the results from some researches $[4,7,10,15]$.

Rising of activation time causes increasing burn-off grade and decrease the activated carbon yield. Obviously, increasing in burn-off represents inclining of weight losses due to activation process. Low burn-off is usually undesirable since they lead to low surface area which, in turn, may lead to a low adsorption capacity for target molecules [1].

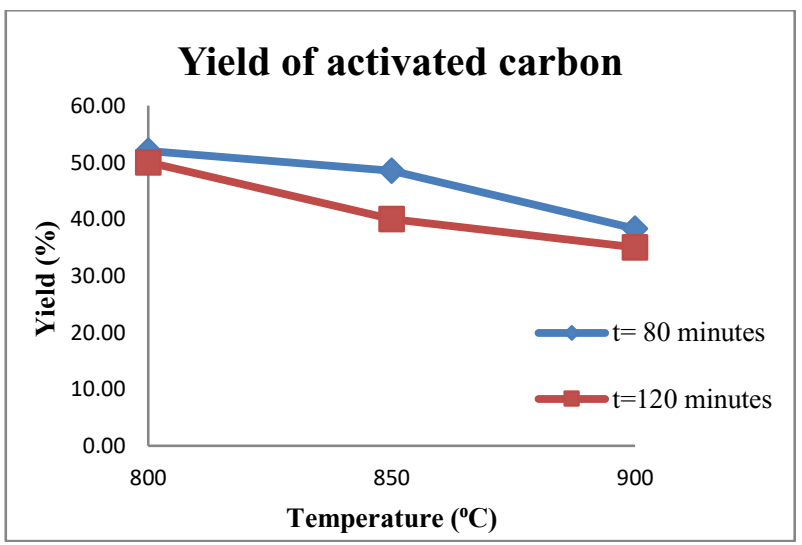

Fig. 2. Yield of activated carbon for temperature and activating time variables

It was evident from Figure 2 that activated carbon yielded from 120 minutes of activation time was lower than one of 80 minutes time. This revealed that prolong of activation time caused improving extent of activation and great reactions among carbon, steam $\left(\mathrm{H}_{2} \mathrm{O}\right)$ and $\mathrm{CO}_{2}$. Chen et.al. [15] summarized the main chemical reactions in the activation process as follow :

$$
\begin{array}{ll}
\mathrm{C}+\mathrm{H}_{2} \mathrm{O} & \longrightarrow \mathrm{H}_{2}+\mathrm{CO} \\
\mathrm{C}+\mathrm{H}_{2} \mathrm{O} \longrightarrow \mathrm{H}_{2}+\mathrm{CO}_{2} \\
\mathrm{C}+\mathrm{H}_{2} \longrightarrow \mathrm{CH}_{4} \\
\mathrm{C}+\mathrm{CO}_{2} \longrightarrow \mathrm{CO}
\end{array}
$$

Here, the volatile materials resulted from longer reaction time was higher, which, therefore it was released leading to reduce activated carbon yield.

Temperature increased would incline a more severe reaction as mention above which, in turn, raised the number of the volatile materials. As shown on Figure 2, activation in higher temperature obtained lower activated carbon yield since much more volatile matter was released.

\subsection{Moisture content}

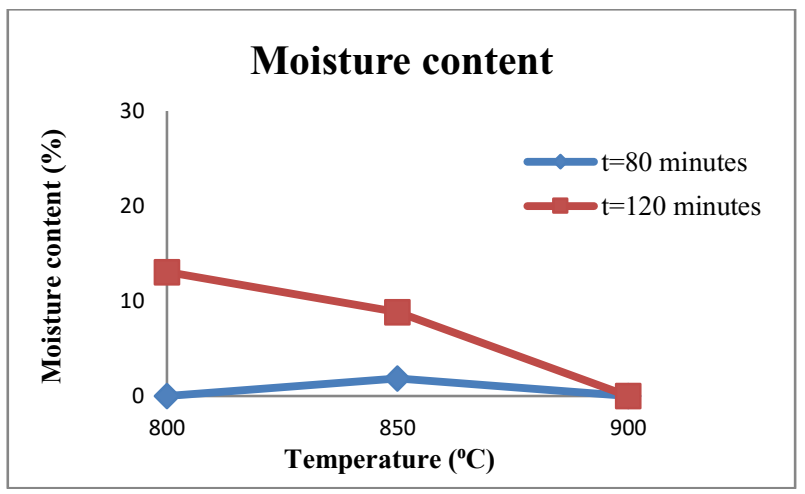

Fig.3. Moisture content at various temperature and activating time

Moisture content is amount of water bound to activated carbon under normal condition. As can be seen from Figure 3, it shows that moisture content of the activated carbon is in the range of $0-13.06 \%$. The moisture 
content of each activation time tended to decline with increasing the temperature.

Based on Indonesian Industrial Standard (SII No. 0258-88), moisture content of activated carbon allowed is not more than $15 \%$. Less moisture content could increase the adsorption capacity of activated carbon.

For activated carbon whose was activation temperature of $800^{\circ} \mathrm{C}$ and $120 \mathrm{~min}$, the moisture content was higher than before activation. This might be caused by activated carbon adsorbed water from the air, due to hygroscopic characteristic, during process of cooling, weighing and packing. Therefore, the handling of activated carbon during the experiment must be appropriate.

\subsection{Ash content}

Ash content indicates amount of residue contained minerals such as calium, natrium, magnesium, calsium, etc. spreads in pores of activated carbon [16]. Ash becomes more concentrate during activation and comprised of $1-20 \%$ depends on the type of raw material. As shown on Figure 4, ash content analyzed was in the range of $12.08-16.59 \%$. It exhibits that ash content was still higher than standard activated carbon in Indonesia, which is $10 \%$ (SII No. 0258-88).

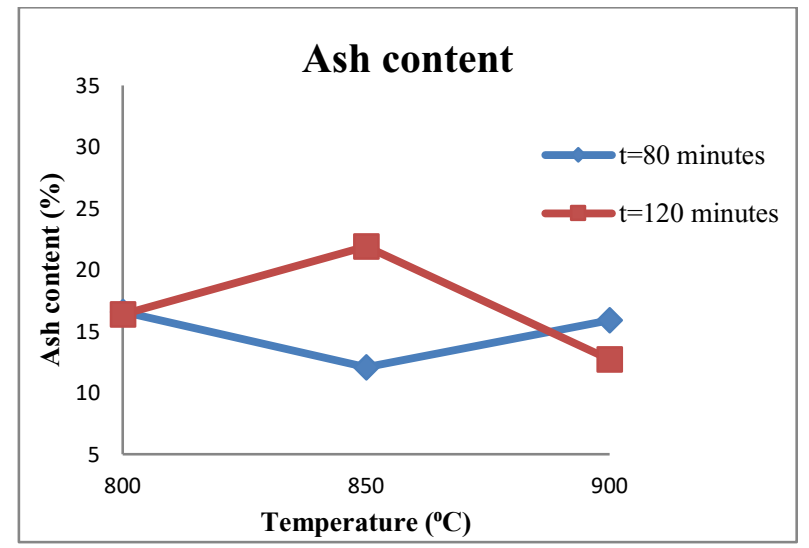

Fig. 4. Effect of activating temperature on ash content of activated carbons

As mentioned above, ash content is influenced by type of raw materials. Activated carbon based on soft by-product materials such as sugarcane bagasse, rice straw, rice husk, has higher ash content due to high minerals content [16]. The previous study obtained that ash content of activated carbon from sugarcane bagasse was various approximately from $9.26-20.26 \%$. While, ash content of bagasse based product was up 42.74\% [1]. Obviously, the presence of twigs (wood base) mixed with sugarcane bagasse in the activated carbon could have effect on the amount of the ash content. High ash content of activated carbon is undesirable since it reduces the mechanical strength of carbon leading to influence adsorption capacity.

\section{4. $\mathrm{pH}$}

The result of $\mathrm{pH}$ measurement was shown on Figure 5. The $\mathrm{pH}$ values were in the range of 9.56-10.54 indicating that all activated carbon produced was alkaline. The $\mathrm{pH}$ values were comparable with some previous experiments $[4,16$,$] . Their studies showed that activated carbon from$ sugarcane bagasse were alkaline, generally, $\mathrm{pH}$ values were above 8.0 due to inorganic compound in raw materials. To gain lower $\mathrm{pH}$ values, approximately 7-8, commercial activated carbon which had $\mathrm{pH}$ values 7.5-9 was washed with $\mathrm{HCl} 0.1 \mathrm{M}$ solution in order to reduce $\mathrm{pH}$ values from 9.4 to 8.5 [4].

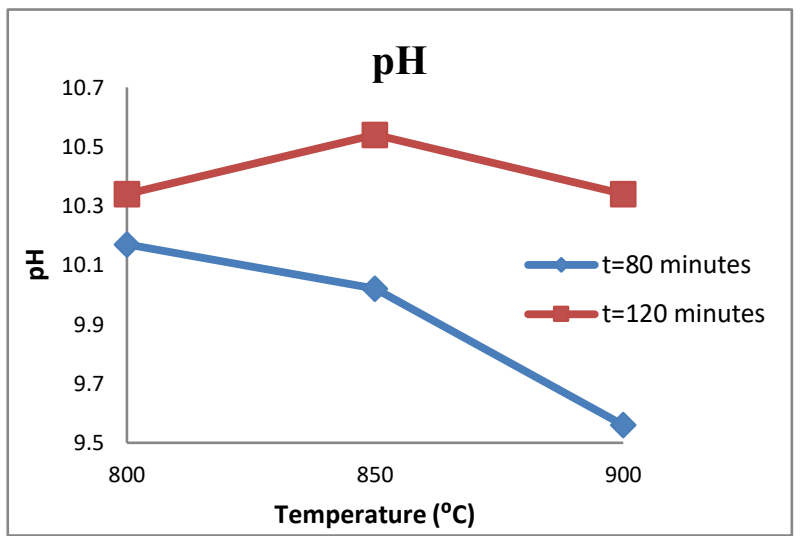

Fig. 5. Effect of activation time and temperature on $\mathrm{pH}$ of activated carbons

From Figure 5, it was shown that rising of activation time will increase $\mathrm{pH}$ value considerably. Increasing $\mathrm{pH}$ was probably caused reduction of $\mathrm{H}_{2} \mathrm{O}$ during activation process leading to increase $\mathrm{OH}$ - ion. As the time retention of activation increased, $\mathrm{OH}$ - ion constantly increased.

\subsection{Methylene blue adsorption}

The adsorptive properties of activated carbon were determined by methylene blue test. Methylene blue number of activated carbon is correlated with ability of the activated carbon to adsorb colour and high molecular weight substances. Figure 6 reflects values of methylene blue adsorbed on the activated carbon. The result of methylene blue adsorption calculated from Equation (3) was in the range of $241.875-242.500 \mathrm{mg} / \mathrm{g}$. The highest adsorption showed at temperature of $850^{\circ} \mathrm{C}$ and $80 \mathrm{~min}$. Besides, percentage of adsorption was also calculated using Equation (4) and the values are displayed on Figure 7. The graphs indicated that percentages of adsorption were quite high, those were in the range of $96.75-$ $98.19 \%$. 


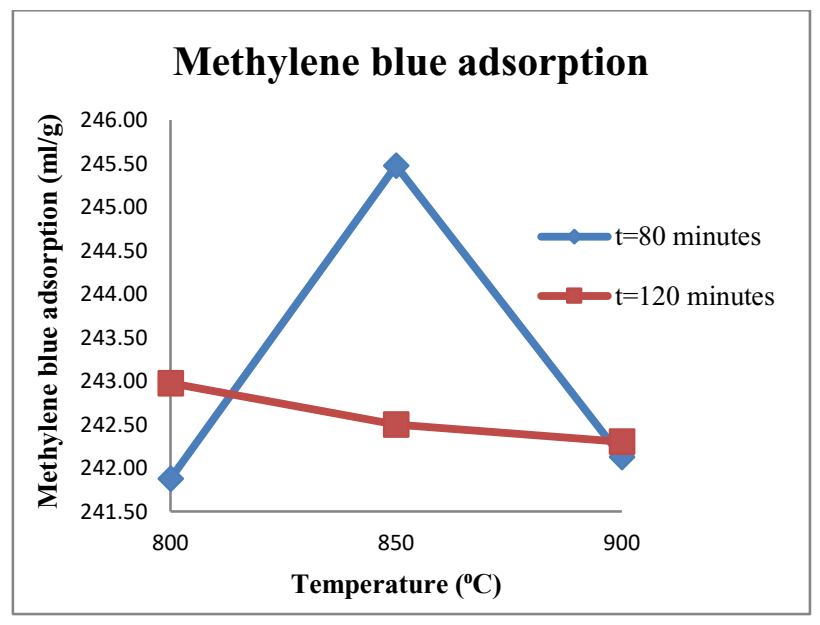

Fig. 6. Effect of activation temperature and time on methylene blue adsorption

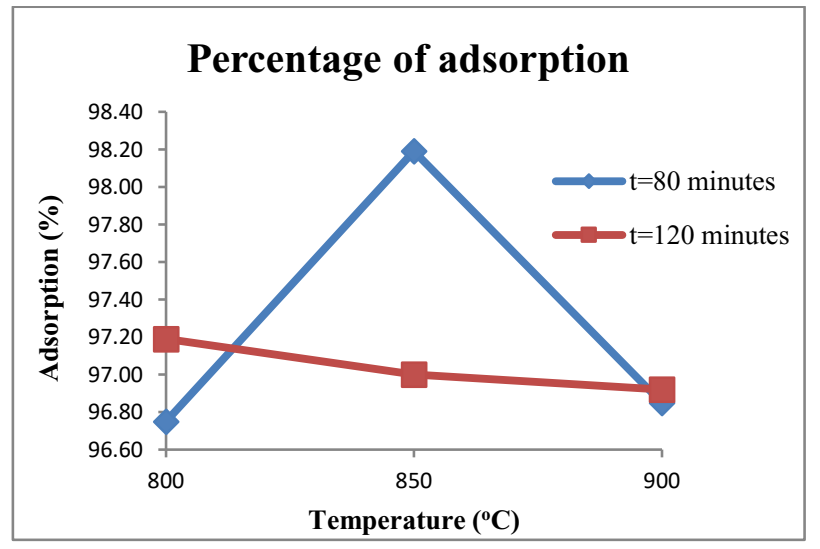

Fig. 7. Effect of activation temperature and time on percentage of adsorption

From Figure 4 reflects that the optimum adsorption of methylene blue was optimum for activated carbon which was activated at temperature of $850^{\circ} \mathrm{C}$ and activation time of 80 minutes. Here, reaction between $\mathrm{CO}_{2}$ and biochar was constant leading to increase number of formed pores. Therefore, it induced to raise methylene blue adsorption significantly. Chen et.al. [15] from their study indicated that lower retention time and higher temperature (above $850^{\circ} \mathrm{C}$ ) could transformed micropores into mesopores or even macropores, resulting in low value of methylene blue adsorption.

In outline, Figure 5 and 7 exhibited that high $\mathrm{pH}$ could increase methylene blue adsorption. This was proportionate with study done by Karacetin et.al. that used activated carbon from Hazelnut Husk [14] and Kumar [17] who used activated carbon from Foxnutshell. The increase in adsorption of $\mathrm{MB}$ with the high $\mathrm{pH}$ was due to the decrease in electrostatic repulsion between the positively charged methylene blue and the surface of the activated carbon. A study revealed that increasing of methylene blue adsorption would be significant in the optimum $\mathrm{pH}$, around 8 . However, the adsorption rate would be slower for $\mathrm{pH}$ above 8 [18]. Activated carbon produced in this study had $\mathrm{pH}$ values approximately 9-10, therefore averagely they would adsorb methylene blue quite highly. It was revealed from Figure 7 that all activated carbon had percentage of adsorption significant, above $90 \%$.

Furthermore, ash content could have impact to adsorption properties. Ash could move freely to cover the existing pores effecting to obstruct adsorption process. It was reflected that methylene blue adsorbed on activated carbon resulted from $850{ }^{\circ} \mathrm{C}$ and 120 minutes activation (AC850/80) was lower than one resulted from $850 \mathrm{oC}$ and 80 minutes (AC850/80). On the other hand, the ash content of (AC850/80) was higher than $(\mathrm{AC} 850 / 80)$ as reflected on Figure 4. Consequently, higher ash content trended to move freely covering existing pores leading to inhibit methylene blue adsorption.

As mentioned before, methylene blue adsorption was influenced by $\mathrm{pH}$ of activated carbon. (AC850/80) had $\mathrm{pH}$ closer to optimum $\mathrm{pH}$ (around 8). This could cause methylene blue adsorbed on (AC850/80) was higher compared to (AC850/120). Eventually, significant methylene blue adsorption on (AC 850/80) could be influenced by $\mathrm{pH}$ and ash content.

Meanwhile, activated carbons resulted from temperature $800^{\circ} \mathrm{C}$ and $900^{\circ} \mathrm{C}$ for two activation times exhibited almost the same adsorption capacity. It could also affected by ash content, $\mathrm{pH}$ and moisture content, where value of each parameter was close each other.

\subsection{Surface area.}

Predicted specific surface area (SSA) using methylene blue method was postulated by El-Geundi [11] and Yukselen [12]. The values showed a deviation compared to specific surface area value of BET analysis. For activated carbon which was alkaline, it exhibited that SSA of methylene blue method was always lower than SSA of BET analysis. The deviation showed up to $77 \%$. While acidic material had higher SSA compared to SSA of BET analysis.

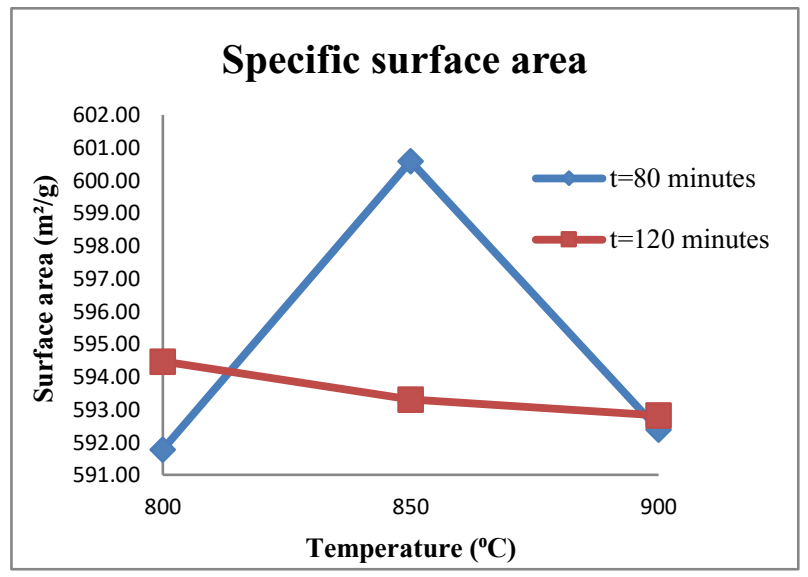

Fig. 8. Predicted specific surface area calculated from methylene blue adsorption

Mass of methylene blue adsorbed was included in the Equation (5) for calculating specific surface area of activated carbon. The surface area represented a variation trend similar to methylene blue adsorption.

The highest surface area showed at temperature $850^{\circ} \mathrm{C}$ and $80 \mathrm{~min}$. 


\section{Conclusion}

Some properties of activated carbon have been analyzed. Moisture content, ash content, and $\mathrm{pH}$ could influence the adsorptive properties of activated carbon. However, the ash content and $\mathrm{pH}$ have significant role in methylene blue adsorption. At this experiment, the optimal activation conditions obtained were $850^{\circ} \mathrm{C}$ and $80 \mathrm{~min}$, where under this condition, the activated carbon yield, moisture content, ash content, $\mathrm{pH}$ values, methylene blue adsorption, and surface area were $52 \%, 0 \%, 12.08 \%, 9.56$, $245.475 \mathrm{mg} / \mathrm{g}$, and $600.584 \mathrm{~m}^{2} / \mathrm{g}$, respectively. It revealed that biochar waste of bio-oil pyrolysis of sugarcane bagasse/twig of rambutan mixture had potential to be a good adsorbent.

The author acknowledge that the financial support provided by Chemical Engineering Dept., Faculty of Industrial Tecnology, University of Islamic Indonesia.

\section{References}

1. K. Qureshi, I. Bhatti, R. Kazi, A. K. Ansari, Int'l. J. Che. Biomolec. Eng., 1:3, 145-149 (2008)

2. B. Sutrisno, N.A. Rizka, A.S. Hidayat, A. Hidayat, IOP Conf. Series: Mat'l Sci. Eng. 105, 12-27 (2016)

3. H.C. Tao, H.R. Zhang, J.B. Li, W.Y. Ding, Bio. Tech., V.192, 611-617 (2015)

4. G.da Cunha Goncalves, N.C. Pereira, M.T. Veit, Biomass and Bioenergy, 85, 178-186 (2016)

5. K.Y. Foo, L.K. Lee, B.H. Hameed, Bio. Tech., V. 134, 166-172 (2013)
6. W. Lismaya, Kayu Sisa Pohon Yang Ditebang Dan Tidak Ditebang Di Iuphhk-Ha Pt Inhutani Ii Unit Malinau Kalimantan Utara, Forest Faculty, Institute Pertanian Bogor, Indonesia (2014)

7. Z. Anwar, M. Gulfraz, M. Irshad, J. Rad. Rsrch and Appl. Sci., 7, 163-173 (2014)

8. A.S. Olawale, O.A. Ajayi, Thermal Activation of Canarium Schweinfhurti Nutshell, Ahmadu Bello University, Zaria, Nigeria (2009).

9. A. Shaabana, S.M. Se, N.M.M. Mitanb, M.F. Dimina, Proc. Eng., 68, 365 - 371 ( 2013 )

10. E. David, J. Kopac, J. Anal. Appl. Pyr., 110, 322-332 (2014)

11. M.S. El-Geundi, E.A. Ashour, R.M.A. Abobeah, N. Shehata, IJSETR, V.3, Issue 8 (2014)

12. Y. Yukselen, A. Kaya, Eng. Geo., 102, 38-45 (2008)

13. Center for Documentation and Information Scientific, LIPI (1997)

14. G. Karacetin, S. Sivrikaya, M. Imamo־glua, J. Anal. Appl. Pyr., 110, 270-276 (2014)

15. D. Chen, X. Chen, J. Sun, Z. Zheng, K. Fu, Bio. Tech., 216, 629-636 (2016)

16. M. Ahmedna, LSU Agricultural Experiment Station Reports 456, Louisiana State University Agricultural Center, USA. (2000)

17. A. Kumar, H.M. Jena, J. Clnr. Prod., 137, 1246-1259 (2016)

18. A.F. Hassana, H. Elhadidy, J. Env. Che. Eng., 5, $955-$ 963 (2017) 